\title{
THE STANDARDISATION OF ANATOMICAL, HISTOLOGICAL AND EMBRYOLOGICAL TERMINOLOGY IN TRANSLATING ENGLISH-BASED ANATOMY TEXTBOOK INTO INDONESIAN
}

\author{
(STANDARDISASI TERMINOLOGI ANATOMI, HISTOLOGI DAN EMBRIOLOGI \\ DALAM MENERJEMAHKAN BUKU TEKS ANATOMI BERBASIS \\ BAHASA INGGRIS KE BAHASA INDONESIA)
}

\author{
Wita Anggraini \\ Department of Anatomy, Faculty of Dentistry, Trisakti University \\ Jl. Kyai Tapa (Grogol), West Jakarta 11440 (Campus B) \\ email: witaang@yahoo.com
}

\begin{abstract}
Anatomical terminology is derived from classical languages, primarily Latin. Latin was used as the language of science until the early 18th century, so all medical textbooks were previously written in Latin. The existence of Latin in the textbooks of anatomy-histology-embryology in Indonesia becomes a challenge for students, lecturers, and researchers because they often have no background knowledge of Latin. The gap in Latin makes English textbooks preferable. English-based anatomy textbooks have been widely translated into Indonesian, but the translation of anatomical terminology in English has no standardization yet. The translations of anatomical terms can be based on several sources, namely: (1) Nomina Anatomica, Nomina Histologica, and Nomina Embryologica; (2) Terminologia Anatomica (TA), Terminologia Histologica (TH), and Terminologia Embryologica (TE); (3) Absorption language by adopting Latin and writing the anatomical terms in accordance with Indonesian spelling; and (4) Translation from English to Indonesian. The aim of this paper was to initiate the selection and determination of the anatomical terms which should be used in Indonesian in order to translate the English-based anatomy textbooks.
\end{abstract}

Keywords: anatomical terminology, translation, English, Latin, Indonesian

\begin{abstract}
Abstrak
Istilah anatomi berakar pada bahasa klasik, terutama dalam bahasa Latin. Bahasa Latin digunakan sebagai bahasa ilmu sampai awal abad ke-18, sehingga semua buku teks kedokteran ditulis dalam bahasa Latin. Keberadaan bahasa Latin di dalam buku teks anatomi, histologi, dan embriologi di Indonesia menjadi tantangan bagi mahasiswa, dosen dan peneliti karena mereka sering tidak memiliki latar belakang pengetahuan tentang bahasa Latin. Kesenjangan dalam bahasa Latin membuat buku teks bahasa Inggris lebih disukai. Buku-buku teks anatomi berbasis bahasa Inggris telah banyak di terjemahkan ke dalam bahasa Indonesia, tetapi penerjemahan istilah anatomi yang berasal dari bahasa Inggris belum ada standarisasinya. Penerjemahan istilah anatomi tersebut ada beberapa versi, ada yang berdasarkan: (1) Nomina Anatomica, Nomina Histologica, dan Nomina Embryologica; (2) Terminologia Anatomica(TA), Terminologia Histologica (TH), dan Terminologia Embryologica (TE); (3) Bahasa serapan dengan cara mengadopsi bahasa Latin dan menuliskan istilah anatomi sesuai dengan ejaan Bahasa Indonesia; dan (4) penerjemahan dari bahasa Inggris ke Bahasa Indonesia. Tujuan dari makalah ini adalah untuk menginisiasi pemilihan dan penentuan istilah anatomi yang harus digunakan ke dalam Bahasa Indonesia dalam rangka penerjemahan buku teks anatomi berbasis di Inggris.
\end{abstract}

Kata kunci: istilah anatomi, penerjemahan, bahasa inggris, bahasa latin, bahasa indonesia 


\section{INTRODUCTION}

Anatomy of the human body is a fundamental basic science which is important for health sciences, especially medical and dentistry science. Medical terms are derived from many languages; mostly from Greek and Latin. The terms originated from Greek mainly occur in clinical terminology while the terms originated from Latin comprise some of the anatomical terms. In addition, there are also medical terms derived from French or Italian. Some examples of terms originated from different languages are neuropathia from Greek (impaired neurological function), cor from Latin (English: heart; Indonesian: jantung), plaque from French (English: plaque; Indonesian: plak), and influenza from Italian (English: influenza; Indonesian: influensa/flu). ${ }^{1}$

The existence of Latin in the anatomy, histology, and embryology textbooks in Indonesia poses a challenge for students, teachers, and researchers because most of them have no background knowledge of Latin. Thus, the gap in Latin results in English-based textbooks is preferable. Moreover, the CompetencyBased Curriculum (CBC) which is implemented based on Problem Based Learning (PBL) and Student Center Learning (SCL) demands medical/dentistry students to learn anatomy, histology, and embryology quickly and accurately. This is followed by a rapid development of various technologies in medical fields that have an impact on the development of biomedical and imaging science too. This development leads to more detailed knowledge lists of anatomical structures. As a result, the new anatomical terms connected to clinical applications have a potential to burden the students. ${ }^{2}$

The anatomy textbooks in Indonesia are usually written in English and published by leading countries, such as America, UK, and Germany. The anatomical terms used in these books are also in English. These books have been translated into Indonesian through various publishers. If we look more closely at some of the translation books, the anatomical terms used are very diverse. Some sources of the anatomical terms vary, namely: (1) Nomina Anatomica, Nomina Histologica, and Nomina Embryologica; (2) Terminologia Anatomica (TA), Terminologia Histologica (TH), and Terminologia Embryologica (TE); (3) an absorption language based on sounds of the Latin pronounciation (e.g. buccinator [Latin] becomes buksinator [Indonesian]); and (4) the translation from English to Indonesian (e.g. muscle [English] becomes otot [Indonesian]).

This diversity can confuse students and young lecturers who have no experience in the learning pattern of anatomy in the past which were based on conti- nuous repetition in Latin or Nomina Anatomica. In the past, the subject of anatomy, histology, and embryology received a large portion in the first and the second year of studying at the Faculty of Medicine and Dentistry, and some even continued until the third year. The decreased number of study hours of the anatomy in the PBL and SCL methods results in the importance of the textbooks to be translated into a good and correct Indonesian. To date, however, there has been no standardization for the anatomical terms in the translation textbooks released by the Indonesian Anatomist Association. Therefore, the purpose of this paper was to initiate the selection of the anatomical terms which will be used in Indonesia.

\section{THE ORIGIN OF THE ANATOMICAL TERMS}

The Ancient Greek was the first nation to study medicine systematically including anatomy and develop a suitable medical vocabulary. The study of vocabulary was continued by the Romans who adopted and necessarily modified the Greek terms to fit their alphabets and grammar. It was then followed by Latin which became the language of science, law, and church in Western Europe until the 18th century. As a result, most of the scientific treatment vocabulary used today comes directly from the Latin roots. Other languages that contribute to medical lexicons include Arabic, Roman, German, Scandinavian, French, Italian, and other languages. ${ }^{1,3}$

Most of the terms used in biology and medicine are derived from Latin or Greek in which the Greek is usually converted into the Latin form. Thus, it is necessary to check the existence of genitive (possessive) and plural forms because a word in Latin is divided into five classes (called declensions), and their cases vary. The examples of the plural forms are $p a-$ pilla, papillae; nucleus, nuclei. However, it is different with the case of ligamentum into ligamenta; and os into ossa. Furthermore, it is also different with the case of dens into dentes, sinus remains sinus in plural form, and согnu into cornua.

The examples of single genitive are levator scapulae, arrector pili, semispinalis capitis, and articulatio genus whereas the examples of plural genitive are levatores costarum, extensor digitorum, vincula tendinum, and confluens sinuum. In addition, adjectives must comply with the noun, so that it becomes $\mathrm{ra}$ mus communicans, rami communicantes; and foramen ovale, fossa ovalis. ${ }^{3}$ 


\section{THE STANDARDIZATION HISTORY OF ANATOMICAL TERMS IN THE WORLD}

Anatomical terminology is the basis for medical communication. This was translated into a nomenclature in Latin. At first, the Latin anatomy nomenclature was published as Basiliensia/Basle Nomina Anatomica (BNA). BNA was an anatomical nomenclature association that started to work in 1887 . The anatomy nomenclature or terminology includes microscopic structures, such as embryology and histology that was transformed into a new international system. The new system was approved in 1895 by the ninth Congress of the society of German-speaking anatomists (Anatomische Gesellschaft) in Basel (later known as Basle), Switzerland. BNA then reduced the number of anatomical terms from 50,000 to about 5,000 by eliminating synonyms. ${ }^{4.5}$

However, BNA failed to be accepted worldwide because it was only used by anatomists from German, Italy, America, and Latin America. The failure of BNA was caused by some reasons, such as: (1) the French anatomists decided to continue their tradition; (2) since 1933, the British anatomists have received the Birmingham Revision (BR) and separated itself from the BNA; and (3) the German anatomists made a revision named Jena Nomina Anatomica (JNA) in 1935. JNA applied a pronograde (horizontal axis) that fit perfectly in the general anatomy of humans and other vertebrates. The BNA, BR, and JNA became the standard of international anatomical terminology until 1955 . $^{6}$

In 1903, Nicolas from Nancy, France, succeeded in establishing the International Federation of Association of Anatomists (IFAA) whose members used the same language for communication purposes. One of the results of this federation was selecting the same nomenclature for anatomical sciences which could be universally accepted. ${ }^{7}$ In the sixth IFAA in 1955, the International Anatomical Nomenclature Committee (IANC) in Paris standardized the anatomical terminology known as Nomina Anatomica (NA). The Sub-Committee of the Nomenclature Committee held a meeting in London in 1954. The Sub-Committee reviewed the recommendations of seven parts of the anatomical sciences including: (1) osteology; (2) syndesmology, myology, and bursae; (3) splanchnology; (4) angiology; (5) central nervous system; (6) peripheral nervous system; and (7) sense organs and general integument. However, the most important discussion in this meeting was a glossary for macroscopic anatomy, including ontogenetic terms and microscopic anatomical terms contained in BNA. In the meeting, 5,640 anatomical terms were accepted in which 4,286 terms were derived from BNA.

Nomina Anatomica was revised in the second edition in 1961 which was released at the seventh IFAA Congress (New York, 1960) whereas the third edition was released at the eighth IFAA Congress in Wiesbaden in 1965. In 1977, after the ninth IFAA Congress in Leningrad in 1970 and the tenth IFAA Congress in Tokyo in 1975, the fourth edition of the Nomina Anatomica was published with Nomina Embryologica and Nomina Histologica by Excerpta Medica, Amsterdam, Oxford. Moreover, at the $11^{\text {th }}$ IFAA Congress in Mexico in 1980, the IANC approved the proposed revision so that the fifth edition of Nomina Anatomica was published together with the second edition of Nomina Histologica and Nomina Embryologica in 1983 as a combined volume. $^{7}$

The sixth edition of Nomina Anatomica became a dispute at the $12^{\text {th }}$ IFAA Congress in 1989. The IANC proposed itself to be an independent organization. As a result, none of the IFAA members was willing to legalize the sixth edition. On August 10, 1989, a new committee, the Federative Committee on Anatomical Terminology (FCAT), was formed. Finally, Terminologia Anatomica (TA) was officially announced in 1997 at the $13^{\text {th }}$ FCAT Congress in Brazil. ${ }^{7,8}$

\section{THE TRANSLATION OF ANATOMICAL, HISTOLOGICAL, AND EMBRYOLOGICAL TERMS INTO INDONESIAN}

Indonesian has absorbed various elements of other languages, either from local languages in Indonesia or from foreign languages, such as English, Dutch, Arabic, and others. For the convenience of translation between languages and future purposes, the international foreign terms should be made through an absorption process. According to the General Guidelines for the Formation of Terms (Pedoman Umum Pembentukan Istilah; PUPI), the absorption process may be made if any of the following conditions are fulfilled, such as: (1) the absorbed term is chosen because its connotation is more suitable; (2) the absorbed term is chosen because it is shorter than the translation in Indonesian; and (3) the absorbed term is chosen because it can facilitate the deal if the Indonesian term has too many synonyms. ${ }^{9}$ The absorption process can be done with or without changes in the spelling and pronunciation. The examples can be seen in Table 1 . 
Table 1. The examples of the absorption process of foreign terms into Indonesian ${ }^{9}$

\begin{tabular}{|c|c|c|}
\hline $\begin{array}{l}\text { Foreign } \\
\text { term }\end{array}$ & $\begin{array}{l}\text { Recommended } \\
\text { as an Indonesian } \\
\text { medical term }\end{array}$ & $\begin{array}{c}\text { Not } \\
\text { recommended as } \\
\text { an Indonesian } \\
\text { medical term }\end{array}$ \\
\hline Urine & Urine & Kencing \\
\hline Amputation & Amputasi & $\begin{array}{l}\text { Pemotongan } \\
\text { anggota badan }\end{array}$ \\
\hline Dysentery & Disenteri & Murus /Mejan \\
\hline Oxygen & Oksigen & Zat asam \\
\hline
\end{tabular}

The terms in Indonesia can be obtained by absorbing and translating foreign terms simultaneously; for example, subdivision into sub-bagian (English: sub-sections). The foreign terms taken may be in the base or derivative form by considering: (1) the context of the situation and the bonding of the sentence; (2) the easiness of the language learning; and (3) practicality. According to PUPI, for the sake of uniformity, the preferred referral source is the English terms that have been used internationally and have been generally accepted by experts in the field. Furthermore, PUPI states that the writing of the terms should be done by prioritizing the spelling of the source language without ignoring the pronunciation (e.g. system into sistem). ${ }^{9}$

However, the absorption of the anatomical, histological, and embryological terms into Indonesian u- sing the ways mentioned above has not been standardized. There are three patterns of the absorption of foreign terms, namely: (1) adopt or take the whole foreign form and meaning; (2) adapt the term by taking only its meaning, but the spelling and writing are adjusted to the Indonesian spelling; and (3) make a creative translation by taking the basic concept that exists in Indonesian. In some anatomy, histology, and embryology books in Indonesian edition, translators usually apply the adaptation method. ${ }^{10}$ When referring to the universal term, the term in Latin becomes the main choice in accordance with the procedure of forming the term. In Table 2, we can see the comparison between terms of anatomy, histology, and embryology in English, Latin, and Indonesian derived from several textbooks.

Table 2. The comparison of anatomical terms in English, Latin, and Indonesian

\begin{tabular}{|c|c|c|c|}
\hline Science & English & Latin & Indonesian \\
\hline Anatomy & $\begin{array}{l}\text { Greater } \\
\text { wing }\end{array}$ & Ala major & $\begin{array}{l}\text { Sayap } \\
\text { besar }\end{array}$ \\
\hline Histology & $\begin{array}{l}\text { Simple } \\
\text { squamous } \\
\text { epithelium }\end{array}$ & $\begin{array}{l}\text { Epithelium } \\
\text { simplex } \\
\text { squamosum }\end{array}$ & $\begin{array}{l}\text { Epitel } \\
\text { gepeng } \\
\text { berlapis }\end{array}$ \\
\hline Embriology & $\begin{array}{l}\text { Pharyngeal } \\
\text { arch }\end{array}$ & $\begin{array}{l}\text { Arcus } \\
\text { pharyngealis }\end{array}$ & $\begin{array}{l}\text { Lengkung } \\
\text { faring }\end{array}$ \\
\hline
\end{tabular}

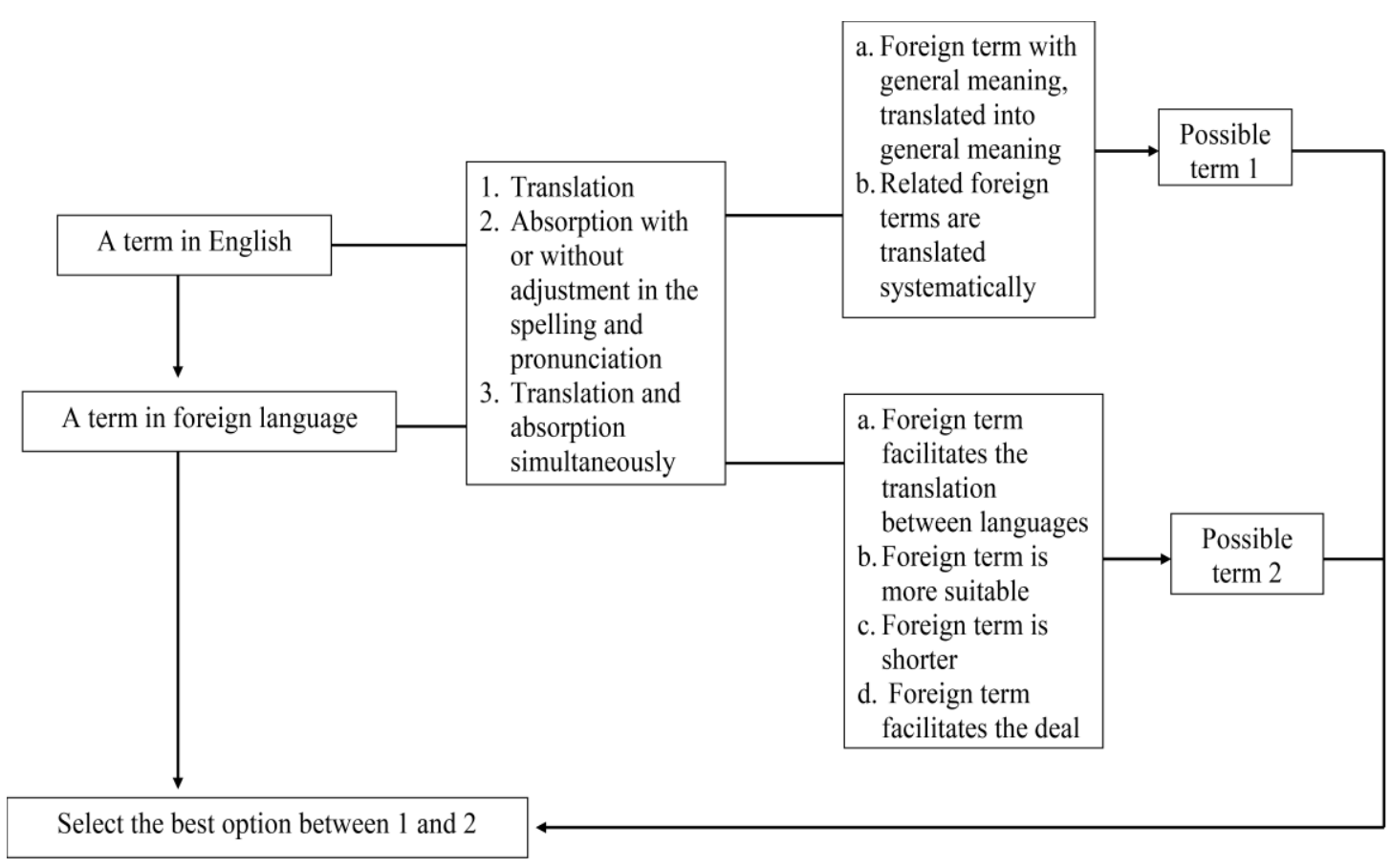

Figure 1. The procedure of forming a term ${ }^{9}$ 


\section{DISCUSSION}

The study of human anatomy has traditionally been an important phase in the learning of a prospective physician / dentist ${ }^{2}$, and anatomy is the key to basic medical science. ${ }^{11}$ Anatomical terminology, therefore, serves as an important basis for describing the human body which is not only for educational and forensic purposes but also for diagnostic and therapeutic procedures. ${ }^{4}$ The terminology of anatomy and histology is rooted in the classical language of Latin as the primary language. Latin was a scientific language until the early $18^{\mathrm{th}}$ century, so all medical textbooks were written in Latin. Under the influence of Andreas Vesalius, the greatest anatomist with his work "De humani corporis fabrica (1543)", anatomical terms were almost exclusively in Latin. According to Whitmore, Latin is a dead language that is no longer developing. In the terminology of this language, there are two characteristics namely "global" and "non-secular". He also described several advantages of using classical languages including persistence, international character, and neutral. $^{12}$

The role of the Latin nomenclature as a basis for understanding is still irreplaceable in medical science. The general rule of the Nomina Anatomica system is that there should be one term for each structure, and the chosen term must have some informative or descriptive values. Although Latin is chosen as the official language, translations into colloquial languages are allowed for teaching purposes. Many anatomical terms in Latin are translated into English while other anatomical terms are never translated. For example, canalis caroticus, and foramen jugulare are always translated into carotid canal, and jugular foramen; whereas foramen lacerum, and dorsum sellae are never translated into English., ${ }^{3,4}$

Anatomical terms have been the subject of much controversy and conflict. Previously, IANC was responsible for issuing the sixth edition of Nomina Anatomica, but this edition was never recognized by IFFA. In 1989, a new committee was formed by IFAA named FCAT. FCAT worked for 9 years to publish Terminologia Anatomica (TA) in 1998. The aims of publishing TA were to democratize anatomical terms and make them internationally accepted or become the life language of anatomy. ${ }^{12}$ In 2015 in Istanbul, IFAA through FIPAT (Federative International Programme for Anatomical Terminology) containing official international standards established human anatomy terminology, finalized, and revised Terminologia Anatomica (TA), Terminologia
Histologica (TH), Terminologia Embryologica (TE), Terminologia Anthropologica (TAnth), Terminologia Odontologica (TO), and Terminologia Neuroanatomica (TNA). ${ }^{13}$

TA is a new standard in anatomical terminology which is only available in Latin and English. TA has been adopted around the world whereas Nomina Anatomica (NA) with previous standards has been widely translated. Fabry et al. in his research stated that more than $75 \%$ of the terms in TA are derived from NA. ${ }^{14}$ After a list of terminology, TA comes with an index of eponyms, Latin terms, and English terms. Terminologia Histologica follows the same structure beginning with the terms of cytology and the general histology of organ system; thus, the arrangement of the TH's content table is similar to that found in TA. ${ }^{15}$

Greathouse et al. stated the need for standard anatomical terminology to facilitate clear communication in health education, clinical research, publications, and professional practice. ${ }^{11}$ American Association of Clinical Anatomy has examined the terminology of clinical anatomy in English. They divide the terminology into four columns in which the first column presents the Latin/Greek term, the second column provides the English translations, and the third and fourth column contain alternative terminology representing historical terms, eponyms, or clinical jargon. The third column presents the most commonly used alternative terminology whereas the fourth column presents a rarely used alternative terminology. ${ }^{16}$ Efforts to standardize anatomical terms will facilitate clinicians in the microscopic/macroscopic examination, imaging technology, and others.

Martin et al. conducted a survey on the frequency of anatomical terms usage among clinical anatomists. The survey results showed that more than $75 \%$ of clinical anatomists paid more attention to synonyms based on TA, and these anatomists were academics who had more experiences in teaching anatomy. In contrast, regular physicians showed a poor understanding of TA. ${ }^{17}$ Kachlick et al. conducted a study of errors in the use of anatomical terminology in clinical practice. He recommended the use of recent revision of Latin anatomical nomenclature (TA) in medical education (theory and clinics), scientific activities, translation, editing, revising, and various publishing activities. Each revision of the anatomical nomenclature should be introduced to the students and doctors to prevent misunderstandings and errors in medical clinical documentation and scientific publications. ${ }^{4,18}$ 
Werneck and Batigalia state that if we want to read a book in the original language which is not in our language, the first thing we should do is learn the original language to understand the text. It is the same case with studying anatomy. Anatomical language is the language which is used for mutual understanding of anatomy without geographical and language boundaries. Terminologia Anatomica serves as a basic communication tool in all medical fields, and the Latin anatomical nomenclature has been repeatedly placed and revised since $1895 .{ }^{19}$

Many problems have appeared due to the use of national nomenclature in non-English speaking countries based on TA, such as Japan, Spain, Brazil, Russia, and some small countries. Nomenclature is a powerful tool in communication to achieve goals and interests. Therefore, to make a multi-language nomenclature, it should be detailed, official, accessible for free on the Internet, so that it can provide good information for anatomists and clinicians. ${ }^{20}$ Non-universal terminology causes extreme confusion. For example, the same structure is known by several names. TA as a new terminology is the result of discussions and consultations around the world containing Latin terms that are equivalent to English. ${ }^{12}$

As the need for Indonesian-based textbooks increases to facilitate the understanding of science, a standardization of anatomical, histological, and embryological terms is required. To date, there has been no standardization of the translation of anatomical terms derived from English which results in emerging diversity of translations. As examples, тиsсulus buccinator (Latin) can be muskulus buksinator or otot buksinator (Indonesian), or cranium (Latin) can be kranium or tengkorak (Indonesian). Although in some translated books into Indonesian, the process of absorption in which the spelling persists in Latin is underlined or in italics ${ }^{9}$, a standardized translation of an English-based anatomy, histology, and embryology textbook is still required. Whether Nomina Anatomica Indonesiana is necessary or not still becomes a controversy in the medical education field in Indonesia because there is a need for universal anatomical language. One of the thought in this paper is whether it is more important to establish Nomina Anatomica Indonesiana or to standardize anatomical language referring to TA along with an understanding of its Latin root language. As a suggestion at the end of this writing, it is preferable from the beginning that medical/dentistry students in Indonesia to learn anatomy using the anatomical terms in TA, TH, and TE rather than having to learn again whenever a universal language is required.

Stuttgard: Thieme, 2010: 1-10.

1. Repaz L. Introduction to medical terminology. In: Repaz L. Basics of medical terminology, Latin and Greek origins: Textbook for $1^{\text {st }}$ year students of medicine. $1^{\text {th }}$ ed., Debrecen: Litográfia Nyomda, 2013: 5 .

2. Tubbs RS, Sorenson EP, Sharma A, Benninger B, Norton N, Loukas M. et al. The development of a core syllabus for the teaching of head and neck anatomy to medical students. Clin Anat 2014; 27(3): 321-30.

3. Catlin B, Lyons J. Introduction. In: basic human anatomy: A Regional Study of Human Structure. Dartmouth Medical School online version 2008: 1.

4. Kachlik D, Baca V, Bozdechova I, Cech P, Musil V. Anatomical terminology and nomenclature: Past, present and highlights. Surg Radiol Anat 2008; 30(6): 459-66.

5. Mulligan M. International anatomical terminology. Skelet Radiol 2006; 35(10): 717-8.

6. Wilson JA. Anatomical nomenclature of fossil vertebrates: standardized terms or "lingua franca"? J Vertebr Paleontol 2006; 26(3): 511-8.

7. IFAA. History of international anatomical terminology. In: IFAA. Federative international program on anatomical terminologies. $3^{\text {rd }}$ revision.
8. Fabry P, Baud R, Burgun A, Lovis C. Amplification of terminologia anatomica by French language terms using Latin terms matching algorithm: a prototype for other language. Int J Med Inform 2006; 75(7): 542-52.

9. Suwardjono. Pedoman umum pembentukan istilah, revisi pusat bahasa Depdiknas. Kepmendiknas RI No:146/U/2004; 2004: 2-4.

10. Andriyani B. Analisis bentuk campur kode dan kata serapan pada ungkapan Ditas pada laman Google. Skripsi. Surakarta: Fakultas Keguruan dan Ilmu Pendidikan Universitas Muhammadiyah Surakarta. 2013:11-13.

11. Greathouse D, Halle J, Dalley A. Terminologia anatomica: Revised anatomical terminology. J Orthop Sport Phys Ther 2004; 34(7): 363-7.

12. Whitmore I. Terminologia anatomica: New terminology for the new anatomist. Anat Rec 1999; 257(2): 50-3.

13. Reports From The Working Groups. Abbreviated Minutes of the 2nd FIPAT Meeting. 2015. <http://www.ifaa.net/index.php/10-fipat/7-aboutfipat> (20 Mei 2016)

14. Fabry P, Baud R, Lovis C. Towards a multilingual 
version of terminologia anatomica. Stud Health Technol Inform 2005; 116: 665-70.

15. Allen WE. Terminologia anatomica: International anatomical terminology and terminologia histologica: International terms for human cytology and histology. J Anat 2009; 215(2): 221.

16. AACA. Clinical anatomical terminology American association of clinical anatomists. $<$ http://www.med.umich.edu/lrc/coursepages/m1/an atomy 2010/html/AnatomicalTerminology.htm> (20 Mei 2016).

17. Martin BD, Thorpe D, DeLuna V, Howard T,
Hagemeyer J, Wilkins N. Frequency in usage of terminologia anatomica terms by clinical anatomists. J Biomed Educ 2014; 2014: 1-9.

18. Kachlik D, Bozdechova I, Cech P, Musil V, Baca V. Mistakes in the usage of anatomical terminology in clinical practice. Biomed Pap 2009; 153(2): 157-62.

19. Werneck AL, Batigalia F. Reflections engendered as a practicing translator concerning the language of anatomy. Rev Bras Cir Cardiovasc 2012; 27(3): 4536.

20. Kachlik D. Anatomical nomenclature and clinical anatomy. Rev Arg Anat Clin 2013; 5(3): 192-3. 